\title{
O chrześcijańskie rozumienie trzeźwości ${ }^{2}$
}

W niniejszym artykule pragniemy zarysować chrześcijańską wizję trzeźwości. W oparciu o teksty pochodzące z Nowego Testamentu zamierzamy odpowiedzieć na pytanie: w jakim sensie chrześcijanin ma być człowiekiem trzeźwym? Faktycznie pytamy więc o zrozumienie tego określenia przez pierwsze pokolenie wyznawców Chrystusa i autorów natchnionych. Wiąże się to z pytaniem o kontekst pouczeń o trzeźwości i motywacji na rzecz postawy określanej jako „trzeźwość" oraz używanej argumentacji ${ }^{3}$.

$1 \quad$ Ks. prof. dr hab. Roman Pindel biskup bielsko-żywiecki. Cenionym biblista, pedagog, profesor biblistyki Uniwersytetu Papieskiego Jana Pawła II w Krakowie, kierownik Katedry Hermeneutyki i Judaistyki. Specjalizuje się w egzegezie Nowego Testamentu.

2 Artykuł opublikowany w „Polonia Sacra” 15/59 (2004), s. 227-253.

3 Literatura na ten temat w języku polskim jest wyjątkowo uboga. Bibliografia biblistyki polskiej za lata 1945-1999 (oprac. P. Ostański) podaje tylko dwa artykuły: S. Cądecki, Trzeźwość według Nowego Testamentu, „Wiadomości Archidiecezji Gnieźnieńskiej" 48 (1993) nr 10, s. 567-577 oraz J. Zawadzki, Zagadnienie trzeźwości w Piśmie Świętym, „Wiadomości Duszpasterskie” 6 (1950), s. 186-190. Ostatnio ukazało się: S. Botul, Trzeźwość w Nowym Testamencie, [w: „Utwierdzaj twoich braci” (Łk 22, 32), red. T. M. Dą̧bek, Kraków-Tyniec 2003, s. 261-276. 


\section{Terminologia dotycząca trzeźwości}

Stwierdzenie „to człowiek trzeźwy” może być rozumiane na co najmniej dwa sposoby. Pierwszy wyznacza negatywny aspekt tego określenia i oznacza stan wykluczający wpływ skutków spożycia alkoholu, zaś jego przeciwieństwem jest stwierdzenie: „ten człowiek jest nietrzeźwy". Druga możliwość rozumienia odnosi się do postrzegania i oceny rzeczywistości oraz podejmowania decyzji. Zgodnie z nią „trzeźwy” to człowiek, który realistycznie, a nie naiwnie czy idealistycznie, postrzega i ocenia. To także ten, kto „na trzeźwo", a więc bez emocji, ale racjonalnie, podejmuje decyzje. W podobny sposób zakres znaczeniowy terminu „trzeźwość” określają słowniki języka polskiego. Najobszerniejszy z nich odnosi to określenie do trzech rzeczywistości: (1) stan przeciwny wobec upicia się, (2) stan przeciwny wobec senności i snu, (3) rzeczowość, liczenie się z realiami ${ }^{4}$.

Zakres znaczeniowy polskiego wyrażenia „być trzeźwym” jest

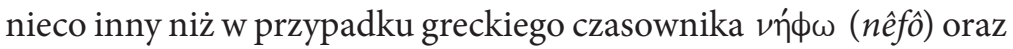
pochodzącego od niego przymiotnika $\nu \eta \phi \alpha ́ \lambda \iota \iota \varsigma$ (nêfalios). Jednostronne znaczenie natomiast przyjmuje poprzedzony przedrostkiem

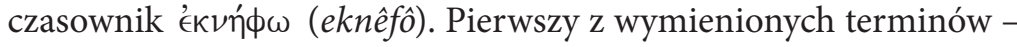
$\nu \eta \dot{\phi} \omega$ (nêfô) - jest najbardziej zbliżony semantycznie do polskiego oznacza: (1) być trzeźwym, nie pić wina, (2) żyć skromnie, z umiarkowaniem, (3) być wstrzemięźliwym, rozważnym ${ }^{5}$. Termin $\nu \eta \phi \alpha ́ \lambda\llcorner o \varsigma$ (nêfalios) jako przymiotnik w odniesieniu do rzeczy oznacza: niezmieszany z winem, zaś do ludzi: trzeźwy. W formie rzeczownikowej ( $\tau \dot{\alpha} \nu \eta \phi \alpha ́ \lambda\llcorner\alpha$ - ta nêfalia) stanowi określenie techniczne dla ofiar

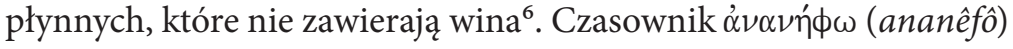

4 Por. Trzeźwość, [w:] Słownik języka polskiego, red. W. Doroszewski, Warszawa 19631969, ad locum.

5 Por. $v$ $\phi \omega$, , [w:] Słownikgrecko-polski, t. II, na podst. słownika Z. Węclewskiego oprac. O. Jurewicz, Warszawa 2000-2001, s. 79.

6 Por. $\nu \eta \phi \alpha ́ \lambda \iota s$, , [w:] Słownikgrecko-polski, t. II, dz. cyt., s. 79. 
można tłumaczyć: wytrzeźwieć, oprzytomnieć, nieraz z jednoznacznym dookreśleniem '́k $\mu$ '́ $\theta \eta \varsigma$ (ek methês) - po pijaństwie ${ }^{7}$. Wreszcie

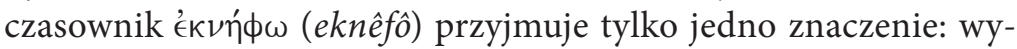
trzeźwieć, wyjść ze stanu nietrzeźwości ${ }^{8}$.

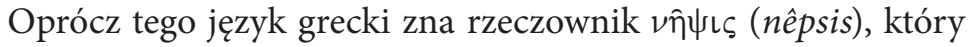
odpowiada polskiemu "trzeźwość" , oraz przymiotnik $\nu \eta \phi \alpha \nu \tau \iota$ เós (nêfantikos), wskazujący na skutek („otrzeźwiający”) lub określający stan („trzeźwy”) ${ }^{10}$. Terminy te jednak nie występują w Nowym Testamencie, te zaś, które znajdziemy, możemy uporządkować wstępnie, biorąc pod uwagę ich znaczenie oraz rozmieszczenie w całym tek-

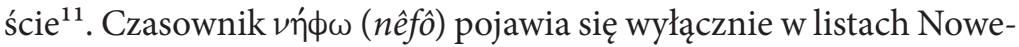
go Testamentu, a więc pismach o charakterze parenetycznym, bądź to z grupy określanej jako Corpus Paulinum (1 Tes 5, 6; 5, 8; 2 Tm 4, 5), bądź w Pierwszym Liście Piotra (1 P 1, 13; 4, 7; 5, 8) $)^{12}$. W tych tekstach ów czasownik nie odnosi się do używania napojów alkoholowych, ale do postawy, którą określają takie cechy jak czujność, uważność, poważne traktowanie życia i jego zagrożeń ${ }^{13}$. Przymiotnik $\nu \eta \phi \alpha ́ \lambda \iota \iota \varsigma$ (nêfalios) występuje jedynie w Listach Pasterskich, w znaczeniu „używać alkoholu według właściwej miary". W takim sensie zastosowany jest on we wskazaniach adresowanych do biskupów (1 Tm 3, 2), do

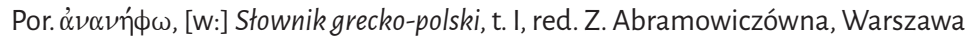
1958, s. 50.

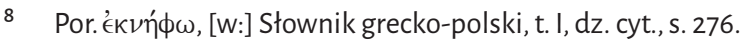

9 W całej Biblii greckiej występuje tylko dwa razy $(\operatorname{Lm} 2,18 ; 3,49)$. Por. $\nu \eta ิ \psi \iota \varsigma, \nu \eta \phi \alpha \nu \tau \iota \kappa o ́ \varsigma$, [w:] Słownikgrecko-polski, t. II, red. Z. Abramowiczówna, Warszawa 1960, s. 79.

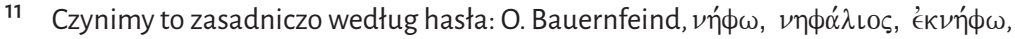
[w:] Theologisches Wörterbuch zum Neuen Testament, Bd. IV, Hrsg. C. Kittel, G. Friedrich, Stuttgart 1942, s. 935-940.

12 Por. $\nu \eta \phi \alpha ́ \lambda\llcorner o \varsigma$, [w:] Exegetisches Wörterbuch zum Neuen Testament, Bd. II, Hrsg. H. Balz, G. Schneider, Stuttgart 1992, s. 1148.

13 Por. E. Lövestam, Über die neutestamentliche Aufforderung zur Nüchternheit, „Studia Theologica"12 (1958), s. 80-102. 
kobiet $(1 \mathrm{Tm} 3,11)$ oraz starszych $(\mathrm{Tt} 2,2)^{14}$. Trzeci termin, $\alpha \nu \alpha \nu \eta \dot{\phi} \phi \omega$ (ananêfô), występuje tylko raz (2 $\operatorname{Tm} 2,26)$ w sensie „oprzytomnieć", ale w znaczeniu przenośnym, bo z kontekstu wynika, że idzie o wyzwolenie od złego wpływu ${ }^{15}$.

Dotychczas omówione terminy nie pojawiają się ani razu w Sep-

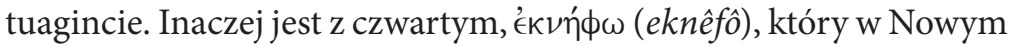
Testamencie występuje raz (1 Kor 15, 34), w greckim tłumaczeniu Starego Testamentu zaś sześć razy (Rdz 9, 24; 1 Sm 25, 37; Syr 31, 2; Jl 1, 5; Ha 2, 7. 19). Nowotestamentowe użycie tego czasownika nie odbiega od wcześniej omówionych terminów ${ }^{16}$. Także przyjmuje znaczenie przenośne, które ze względu na kontekst można oddać przez „ocknąć się" z niewłaściwego stanu pod względem świadomości moralnej ${ }^{17}$.

$\mathrm{Z}$ tego przeglądu tekstów nowotestamentowych zawierających terminy posiadające rdzeń $\nu \eta \phi$ - (nêff) wynika, iż zawierają one cechę semantyczną, stanowiącą opozycję wobec cechy, którą możemy określić jako „odurzenie”. W przypadku tej grupy, do której należy czasownik $\nu \eta \dot{\phi} \omega$ (nêfô), idzie o brak „odurzenia” w sensie dosłownym lub przenośnym ${ }^{18}$. Przeciwnym zaś co do znaczenia wobec ostatniego czasownika jest $\mu \in \theta \dot{\omega} \omega$ (methyô) ${ }^{19}$.

W naszym artykule tylko doraźnie, w razie konieczności, odwoływać się będziemy do tekstów zawierających terminy bliskoznaczne wobec słów posiadających wspólny rdzeń z czasownikiem $\nu \eta \dot{\phi} \phi \omega$

14

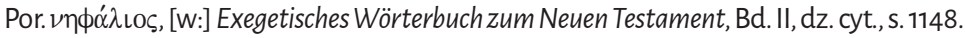

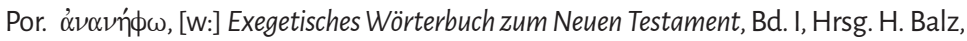
C. Schneider, Stuttgart 1992, s. 205.

16 W Starym Testamencie zaś przyjmuje różne znaczenia, w tym i „wytrzeźwieć po upiciu się winem" (por. Rdz 9, 24; 1 Sm 25, 37).

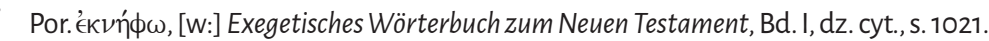

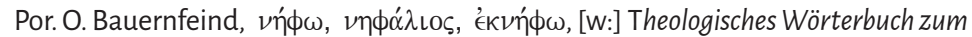
Neuen Testament, Bd. IV, dz. cyt., s. 935.

Ten czasownik w greckiej Biblii występuje 17 razy ( $1 \mathrm{Sm} \mathrm{1,} \mathrm{13;} \mathrm{25,} \mathrm{36;} 1 \mathrm{Krl} 16,9 ; 21,16$; Ps 106, 27; Hi 12, 25; ]l 1, 5; Iz 19, 14; 24, 20; 28, 1; 51, 21; 58, 11; Mt 24, 49; Dz 2, 15; 1 Kor 11, 21; 1 Tes 5, 7; Ap 17, 6). 
$(n \hat{e} f \hat{o})^{20}$. Wspomnimy w tym miejscu jedynie o czasowniku $\sigma \omega \phi \rho \hat{o}$ $\nu \in$ $\omega^{\prime}$ (sôfroneô), który określa „trzeźwe myślenie” w znaczeniu „właściwej oceny siebie" (Rz 12, 3), innym razem jako stan przeciwny ekstatycznemu (2 Kor 5, 13) czy „zachowanie zdrowe pod względem psychicznym" (Mk 5, 15; Łk 8, 35), ale także jako zdolność panowania

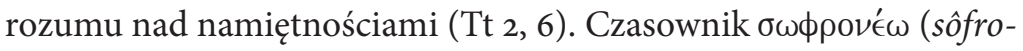
neô) raz występuje w parze $\mathrm{z}$ interesującym nas czasownikiem $\nu \eta \dot{\phi} \phi \omega$ (nêfô) w znamiennym wezwaniu: „Bądźcie więc roztropni i trzeźwi ( $\sigma \omega \phi \rho о \nu \eta ́ \sigma \alpha \tau \epsilon \ldots \kappa \kappa \iota ~ \nu \eta ́ \psi \alpha \tau \tau)$ dla modlitwy" (1 $\mathrm{P} 4,7)^{21}$. W podobny sposób wstępnie zasygnalizujemy występowanie innego czasowni-

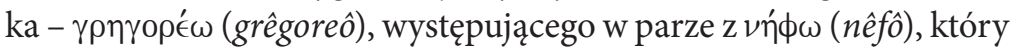
przyjmuje znaczenie: „czuwać” (1 Tes 5, 6; 1 P 5, 8) 22 .

Bliższe określenie rozumienia trzeźwości w pismach Nowego Testamentu może przybliżyć analiza stosownych tekstów, do której przechodzimy.

\section{Chrześcijańska trzeźwość ze względu na przyjście Pana (1 Tes 5, 6. 8)}

Pierwszy tekst traktujący o postawie trzeźwości pochodzi z pisma, które przyjmuje się za najwcześniej zredagowane spośród ksiąg

Słownik terminów nowotestamentowych, porządkujący je według pól znaczeniowych, umieszcza wszystkie przywoływane przez nas słowa w grupie „To Think, Thought", obejmującej w sumie 38 pozycji. Zostały one tak ułożone ze względu

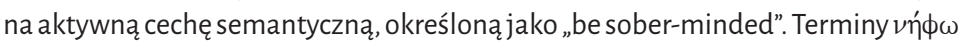
oraz $\nu \eta \phi \alpha ́ \lambda$ เo $z$ zalazły się w jeszcze jednej grupie: „Self-Control, Lack of Self-Control”, obejmującej 10 pozycji, ze względu na cechę semantyczną „, be restrained". Por. Louw-Nida Creek-English lexicon of the New Testament. Based on semantic domains, ed. J. P. Louw, E. A. Nida, New York 1988, ad locum.

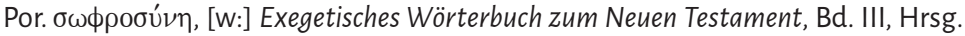
H. Balz, G. Schneider, Stuttgart 1992, s. 790-792.

22 Jego pierwotne znaczenie to „nie spać”; por. $\gamma \rho \eta \gamma$ zum Neuen Testament, Bd. I, dz. cyt., s. 638. 
Nowego Testamentu. Tekst ten stanowi wezwanie do czujności z tej racji, że czas powtórnego przyjścia Chrystusa jest nieznany (1 Tes 5, 1-11). Przytoczmy to Pawłowe wezwanie w dosłownym tłumaczeniu:

Wy zaś, bracia, nie jesteście w ciemności, by ten dzień miał was zaskoczyć jak złodziej. Wy wszyscy bowiem jesteście synami światłości i synami dnia. Nie jesteśmy [z] nocy ani [z] ciemności. Więc abyśmy nie spali jak inni, lecz czuwajmy i bądźmy trzeźwi

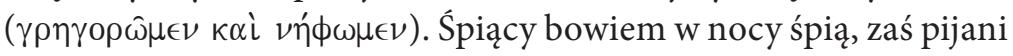
w nocy się upijają. My jednak, do dnia należący, bądźmy trzeźwi, uzbrojeni w pancerz wiary i miłości oraz hełm nadziei zbawienia. (1 Tes 5, 4-8)

Przywołany tekst jednoznacznie wprowadza dychotomiczny podział na dwie komplementarne pory doby i właściwe im aktywności oraz na dwie grupy ludzi, którzy przyjmują diametralnie różne postawy. Z porą nocną wiąże się sen, upijanie, brak czujności i wystawienie się na niebezpieczeństwo bezkarnego działania złodzieja. Z dniem i jasnością w sposób oczywisty związane jest czuwanie i trzeźwość, rozumiane jako aktywność codzienna oraz sprawność psychiczna, co zasadniczo wyklucza możliwość przeoczenia ważnych wydarzeń ${ }^{23}$. Wersety $5,4-5$ zawierają opozycje światłość - ciemność oraz dzień - noc, które tworzą konstrukcję chiastyczną ${ }^{24}$ :

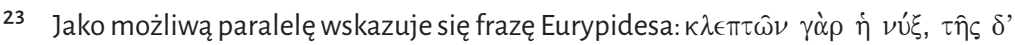

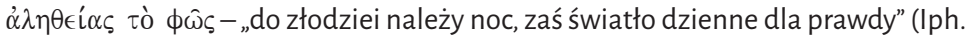
in Taur. 1026). Na temat użycia antytezy światłość - ciemność w pouczeniach parenetycznych Świętego Pawła pisał polski biblista: L. R. Stachowiak, Die Antithese Licht-Finsternis - ein Thema der paulinischen Paränese, „Theologische Quartalschrift" 143 (1963), s. 385-421.

24 Por. T. Holtz, Der erste Brief an die Thessalonicher, Zürich 1986, s. 222 (Evangelisch--Katholischer Kommentar zum NT [dalej: EKK], XIII). 


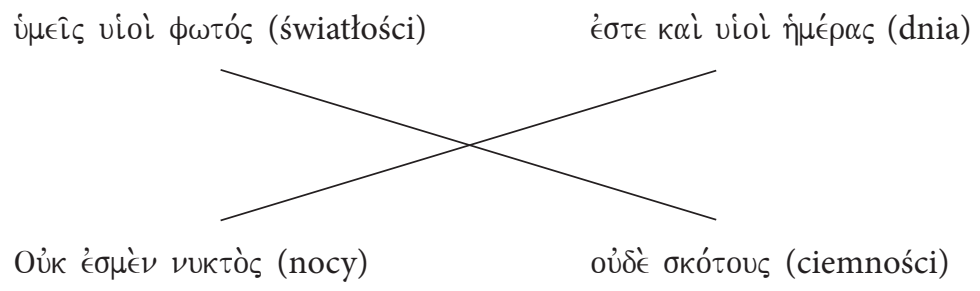

Tekst wzywa wyraźnie do jednoznacznego opowiedzenia się przez uznanie programowej logiki, która zawarta jest w 1 Tes 5, 4: „nie jesteście w ciemności, by ten dzień miał was zaskoczyć jako złodziej”. Idzie o „ów dzień”, czyli powtórne przyjście Pana, którego jednym z ważniejszych aspektów jest nieznany czas jego nadejścia, jak to wyraźnie stwierdza Paweł we fragmencie: „Sami bowiem dokładnie wiecie, że dzień Pański przyjdzie tak, jak złodziej w nocy" (1 Tes 5, 2). Przywołany przez nas tekst (1 Tes 5, 4-8) zawiera pouczenie odnośnie do tego, jak żyć za dnia i w nocy, a być równocześnie zawsze gotowym na powtórne przyjście uwielbionego Pana.

Pewne światło na Pawłowe wezwanie do trzeźwego zachowania ze względu na nadchodzący dzień Pana rzuca archeologia oraz próby rekonstrukcji życia religijno-obyczajowego w Tesalonice w epoce apostoła $^{25}$. Okazuje się, iż w tym mieście Dionizos czczony był już prawdopodobnie ok. 500 roku przed Chr., zaś oficjalny i bogaty kult tego boga w postaci obchodów istniał już 100 lat przed przybyciem tam Pawła. Ważnym elementem kultu było coroczne obchodzenie zakończenia winobrania, połączone z tańcami, nocnymi ucztami i piciem dużych ilości młodego wina, wręcz po to, by się upić ${ }^{26}$. Zdaniem

Szerzej na ten temat w napisanej pod moim kierunkiem i obronionej rozprawie doktorskiej: W. Kic, Misja macedońska Pawła Apostoła wświetle źródeł archeologicznych, praca doktorska, Uniwersytet Papieski Jana Pawła II, Kraków 2004 [maszynopis].

Te i inne aspekty misteriów dionizyjskich oraz różnych, związanych z nimi obrzędów przybliża R. Merkelbach, Die Hirten des Dionysos. Die Dionysos-Mysterien der römischen Kaiserzeit und der bukolische Roman des Longus, Stuttgart 1988. 
niektórych komentatorów tego typu „obyczajowość” była powodem Pawłowego napomnienia przed nadużywaniem alkoholu w tekście 1 Tes 5, 6- $8^{27}$. Zastosowany przez apostoła podział ludzi na tych, którzy należą do dnia, i na tych, którzy należą do nocy, może przypominać adresatom o istnieniu w tym mieście stowarzyszeń kultowych związanych z Dionizosem, o charakterze wyraźnie elitarnym, które obejmowały jedynie „mistów”, czyli wtajemniczonych ${ }^{28}$.

Choć w takich realiach żyją chrześcijanie w Tesalonice, to jednak Pawłowe wezwanie do bycia trzeźwym nie wyczerpuje się w przyjęciu negatywnej postawy wobec używania napojów alkoholowych. Nie występuje on przeciwko umiarkowanemu używaniu wina do posiłków wieczornych. Naganne jest zaś na pewno nadużywanie, ale przede wszystkim próba życia za dnia w sposób, w jaki poganie tylko w nocy postępują. Naganny styl życia, właściwy dla nocy, apostoł przypisuje ludziom, do których nie dotarła jeszcze Dobra Nowina. Adresaci listu zaś są ludźmi żyjącymi według norm dnia, co Paweł trzykrotnie podkreśla w tak krótkim fragmencie tekstu. Wpierw stwierdza: „Wy wszyscy jesteście bowiem synami światłości i synami dnia” (1 Tes 5, 5a), następnie, identyfikując się $\mathrm{z}$ adresatami: „Nie jesteśmy $[\mathrm{z}]$ nocy ani [z] ciemności" (1 Tes 5, 5b), wreszcie za oczywiste założenie dla dalszych pouczeń przyjmuje: „My jednak, do dnia należący [...]” (1 Tes 5, 8a).

Adresaci żyją zarówno w dzień, jak i w nocy, zawsze jednak w sposób właściwy dla dnia, a to ze względu na dzień Pana, który jest u progu ${ }^{29}$. Nie jakoby nigdy nie kładli się do snu czy nie mieli używać

27 Tak m.in. R. Jewett, The Thessalonian correspondence. Pauline rhetoric and millenarian piety, Philadelphia 1986, s. 127 oraz Ch. vom Brocke, Thessaloniki-Stadt des Kassander und Cemeinde des Paulus. Eine frühe christliche Cemeinde in ihrer heidnischen Umwelt, Tübingen 2001, s. 129 (Wissenschaftliche Untersuchungen zum Neuen Testament, 125).

28 Na temat różnych greckich stowarzyszeń kultowych, w tym i dionizyjskich, pisał F. Poland, Ceschichte des griechischen Vereinswesens, Leipzig 1967.

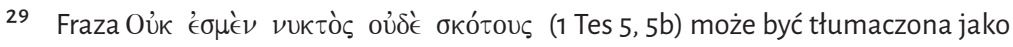
„nie jesteśmy synami nocy ani ciemności”, ale lepiej oddać ją jako „nie jesteśmy 
wina do posiłków. Oni zawsze „należą do dnia” (1 Tes 5, 8), także w nocy, ale nie popełniają mrocznych czynów, które noc skrywa. Należą do eschatologicznej sfery, która się już otwarła i obejmuje tych należących do Pana już pomiędzy zmartwychwstaniem a paruzją ${ }^{30}$. Jeżeli bowiem apostoł wzywa, by „nie spali, jak inni” (1 Tes 5, 6a), to chodzi mu nie tyle o zupełne zaniechanie snu, ile o czuwanie w znaczeniu odpowiedniego stylu życia ${ }^{31}$. Wyraża to słowami „czuwajmy i bądźmy trzeźwi” (1 Tes 5, 6b), które zawierają wezwanie do takiego postępowania, by być gotowym w każdym momencie na przyjście Pana i Jego sąd. To zakłada życie, w którym nawrócenie od „uczynków ciemności” się już definitywnie dokonało, zaś wierzący oczekuje z niecierpliwością tego dnia odsłaniającego czyny ludzi (por. 1 Kor 3, 13) w przekonaniu, że w jego przypadku są to czyny godne „syna światłości”. Tym samym dochodzi do głosu Pawłowa zasada, którą można określić jako „Bądź tym, kim jesteś", a co wyraża w przypadku czasowników w tekście przejście od form trybu orzekającego do rozkazującego ${ }^{32}$.

O tym, że trzeźwość i czuwanie mają charakter moralnej postawy, przekonuje dalsze wskazanie Pawła, w którym podaje on dodatkowe czynności właściwe dla człowieka oczekującego Pana. Nie środki na pozbycie się naturalnej senności czy usuwające skutki nadużycia alkoholu, ale „uzbrojenie w pancerz wiary i miłości oraz hełm nadziei zbawienia" $(1 \text { Tes } 5,8)^{33}$. To zaś wskazuje, że orężem wierzącego jest

z nocy ani z ciemności”. Tu ma bowiem zastosowanie dopełniacz, który bywa określany jako „Hebrew genetiv" (lub „attributive” czy "qualitative”); por. M. Zerwick, Biblical Creek, Rome 1987, s. 14-16 (§ 43).

Por. F. Laub, 1. und 2. Thessalonicherbrief, Würzburg 1988, s. 31 (Die Neue Echter Bibel [dalej: NEB], 13).

O czasowniku к $\alpha \theta \in v ́ \delta \omega$ (spać), który w krótkim odcinku tekstu występuje aż trzykrotnie (1 Tes 5, 6. 7. 10), za każdym razem w innym znaczeniu, traktuje T. Holtz, Der erste Briefan die Thessalonicher, dz. cyt., s. 222.

Por. F. Laub, 1. und 2. Thessalonicherbrief, dz. cyt., s. 31. 
głównie postawa wynikająca z wiary, wyczekująca przede wszystkim łaski Boga. Odpowiada to sytuacji żołnierza przed decydującą bitwą - nie tylko dba on o trzeźwość jako wolność od skutków nadużycia alkoholu, ale także o sprawność psychiczną oraz o odpowiednie przygotowanie pod względem uzbrojenia ${ }^{34}$. W tle tego pouczenia pozostaje znane $\mathrm{z}$ ewangelii (por. Mt 24, 43; Łk 12, 39) ostrzeżenie przed złodziejem, który przychodzi w nocy i w ten sposób zaskakuje gospodarza. Gdyby ten ostatni wiedział, że tak się stanie, czuwałby, by nie dopuścić do szkody. Wspólna dla adresatów listu oraz bohatera tej przypowieści jest gotowość na uczynienie wszystkiego, by nie być zaskoczonym i nieprzygotowanym $(1 \text { Tes } 5,6)^{35}$.

Trzeźwość jako wolność od upojenia alkoholem jest podstawowym warunkiem bycia chrześcijaninem, zrozumiałym sam przez się. Dla tego, kto chce być gotowym w każdym czasie na przyjście Pana, trzeźwość to nowy styl życia, odcinający się od obyczajów pogan. To oczekiwanie z niecierpliwością objawienia się „owego dnia”.

Motyw przeciwstawienia aktywności nocnej wobec dziennej, który służył ukazaniu takiego rozumienia trzeźwości, pojawi się w kolejnej omawianej perykopie ( $\mathrm{Rz} 13,10-13)$. Wspólny motyw może wskazywać na jakąś wcześniejszą tradycję, ale także na związek obu tekstów z tymi, które przynależą do ewangelicznych fragmentów o charakterze apokaliptycznym ${ }^{36}$.

34 Por. J. Stępień, Listy do Tesaloniczan i Pasterskie. Wstęp - przekład - komentarz, Poznań 1979, S. 194 (Pismo Święte Nowego Testamentu w 12 tomach, 9).

35 Por. F. F. Bruce, Word biblical commentary, Vol. 45, 1 \& 2 Thessalonians, ed. D. A. Hubbard, G. W. Barker, R. P. Martin, Dallas 1998, ad locum.

36 Na temat redakcji i ewentualnych wcześniejszych tradycji obecnych w tekście traktuje: B. Rigaux, Tradition et rédaction dans 1 Th. V.1-10, „New Testament Studies” [dalej: NTS] 21 (1974-1975), s. 318-340. Dyskutowana jest przede wszystkim zależność perykop opisujących paruzję w Pierwszym Liście do Tesaloniczan z eschatologicznymi fragmentami ewangelii synoptycznych. 


\section{Trzeźwość jako wolność od niewłaściwego używania}

(Rz 13, 13; Tt 2, 2-3)

Drugi tekst zawierający wezwanie do trzeźwości pochodzi z Listu do Rzymian (Rz 13, 11-14), a więc z pisma późniejszego od Pierwszego Listu do Tesaloniczan o ponad pięć lat, a i problematykę powtórnego przyjścia Pana podejmującego w sposób o wiele bardziej spokojny i raczej marginalny, gdy zważy się całość wywodów tego doktrynalnego pisma. Interesujące nas wskazania umieszcza apostoł w partii parenetycznej, w kontekście różnych pouczeń odwołujących się do miłości (Rz 12, 3-13, 10). Pomimo upływu lat od sformułowania słów skierowanych do Tesaloniki, a także innego adresata ujęcie wezwania do trzeźwości pozostaje podobne. Bo też idzie o podstawową dyspozycję chrześcijanina ze względu na powtórne przyjście Pana. Jak ukazuje to Pawłowe wezwanie:

Jesteście świadomi co do tego momentu, że nadszedł czas waszego powstania ze snu, teraz bowiem zbawienie jest bliżej nas niż wtedy, gdyśmy uwierzyli. Noc przeszła a dzień blisko. Odłóżmy więc czyny ciemności, uzbrójmy się w zbroję światłości. Jak w dzień, przyzwoicie postępujmy: nie w obżarstwach i pijatykach, nie w nierządzie i wyuzdaniu, nie w sporze i zawiści. Lecz uzbrójcie się w Pana Jezusa Chrystusa, zaś o potrzeby ciała zbytnio się nie troszczcie, dla pożądań. (Rz 13, 11-14)

Interesuje nas szczególnie pozytywne wezwanie: „Jak w dzień, przyzwoicie postępujmy" ( $\mathrm{Rz} 13,13 \mathrm{a})$, doprecyzowane jednak w sposób negatywny: „nie w obżarstwach i pijatykach, nie w nierządzie i wyuzdaniu, nie w sporze i zawiści" ( $\mathrm{Rz} 13,13 \mathrm{~b})$. Łatwo w tym ostatnim wykazie dostrzec trzy pary terminów, które stanowią określenia bliskoznaczne wobec siebie. Są one w sposób schematyczny oddzielone od siebie, jak to przedstawia poniższe zestawienie, ukazujące symetrię równoległą: 


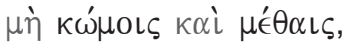

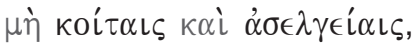

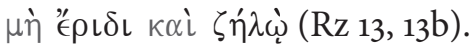

Nie ulega też wątpliwości, iż ten wykaz zawiera określenia zachowań, które mają zdecydowanie negatywny wpływ na życie wspólnoty chrześcijańskiej. Znamienne, że na początku znajduje się para terminów odnoszona do spotkań towarzysko-religijnych, negatywnie

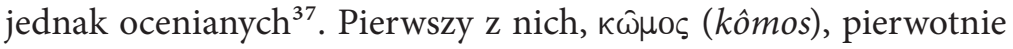
odnosił się do uroczystego pochodu ku czci Dionizosa, później wystawnych uczt ${ }^{38}$. Drugi termin, $\mu$ '́ $\theta \eta$ (methê), co do znaczenia komplementarny wobec poprzedniego, jednoznacznie odnosi się do nadużywania alkoholu. W całym Nowym Testamencie występuje on jedynie trzy razy, zawsze w wykazach czynów nagannych (Łk 21, 34; $\mathrm{Rz} 13,13 ; \mathrm{Ga} 5,21)^{39}$.

Analizowany aktualnie fragment naznaczony jest podobną opozycją co wcześniej omówiony z Listu do Tesaloniczan: nocy i czynom ciemności przeciwstawione zostały dzień i przyzwoite postępowanie, do tego zaś dochodzi stwierdzenie, iż noc minęła i należy żyć, jak przystało w dzień ( $\mathrm{Rz} 13,12)$. Przynagla do tego przypomnienie, że

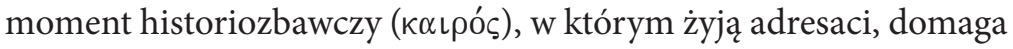
się przyjęcia postawy właściwej dla powstałych ze snu (Rz 13, 11a). Wzmacnia to przypomnienie ważne stwierdzenie co do przemijania czasu i przybliżania się dnia powtórnego przyjścia Pana, niezależnie od tego, kiedy by nie nastąpiło ( $\mathrm{Rz} 13,11 b)$. Jeżeli jest bliżej, to w konsekwencji należałoby być bardziej na ów dzień przygotowanym.

37 To, co mogli oglądać na własne oczy adresaci listu w Rzymie, opisuje Swetoniusz w swoich Żywotach cezarów (Neron 26, 2-3); por. U. Wilckens, Der Briefan die Römer. 3. Teilband, Röm 12-16, Zürich 1989, s. 77 (EKK VI/3). Por. $\kappa \hat{\omega} \mu \mathrm{s}$, [w:] Exegetisches Wörterbuch zum Neuen Testament, Bd. II, dz. cyt., s. 825.

39 Por. $\mu \epsilon^{\prime} \theta \eta$, [w:] Exegetisches Wörterbuch zum Neuen Testament, Bd. II, dz. cyt., S. 987. 
Przesłanie całego wezwania jest jednoznaczne: to, co w świecie pogańskim bywa dopuszczalne ze względu na porę nocną (uczty, obżarstwa, pijatyki, zachowania wyuzdane i niemoralne $)^{40}$, dla wierzących jest zawsze niedopuszczalne ${ }^{41}$. Dotyczy to na pewno nadużywania alkoholu, zwłaszcza w ramach takich uczt, które zwykło się określać jako pijackie.

Trzeźwość rozumiana jako powstrzymywanie się od udziału w ucztach, w których dochodzi do pijatyk, należy do postaw właściwych dla chrześcijan, którzy oczekują na przychodzącego Pana. To jedna z cnót, której obrońcą jest sam Chrystus, jeżeli tylko zostanie przez wyznawcę za takiego przyjęty (Rz 13, 14). Użyty w tym fragmencie czasownik ' $€ \nu \delta$ ú (endyô) ze względu na paralelę do 1 Tes 5, 8 należałoby rozumieć nie tylko w sensie „odziać się”, ale też „uzbroić się" - w samego Pana. Argumentacja na rzecz trzeźwości jako wolności od zachowań sprzecznych z godnością chrześcijanina wiąże się z wezwaniem do troski, z pomocą łaski (uzbroić się w Pana Jezusa), o życie odpowiadające godności człowieka, jego powołania i sytuacji zbawczej $^{42}$.

Podobne jak w Liście do Rzymian pouczenia na temat trzeźwości można znaleźć w Liście do Tytusa (Tt 2, 2-3). W tym zredagowanym ostatecznie na pewno dużo później liście wezwanie do umiaru w używaniu wina pomieszczone zostało w partii określającej właściwe postępowanie różnych grup tworzących Kościół domowy. Partia interesującego nas tekstu jest wyraźnie wyodrębniona (Tt 2, 1-15), nie tylko tematycznie, ale także przez inkluzję

40 Teksty wyrażające przekonanie starożytnych, iż noc pokrywa zachowania niemoralne, zawiera antologia: C. Strecker, U. Schnelle, Neuer Wettstein. Texte zum Neuen Testament aus Criechentum und Hellenismus, Bd. II, Berlin 1966, S. 207-210.

41 Por. E. Lohse, Der Brief an die Römer, Göttingen 2003, s. 366 (Kritisch-exegetischer Kommentar über das Neue Testament).

42 Por. U. Wilckens, Der Briefan die Römer, dz. cyt., s. 77. 
$\left(\lambda \alpha \dot{\alpha} \lambda \in \mathrm{L}\right.$ w Tt 2, 1 i 2, 15) ${ }^{43}$; stanowi ona Haustafel: wymienia wpierw obowiązki starszych mężczyzn (Tt 2, 2) i starszych kobiet (Tt 2, 3-5), następnie młodych mężczyzn (Tt 2, 6-8), niewolników (Tt 2, 9-10) oraz wszystkich (Tt 2, 11-14). Wezwanie do umiarkowania w używaniu alkoholu skierowane jest jedynie do osób starszych, dlatego tylko je przywołujemy:

Starsi trzeźwymi ( $\nu \eta \phi \alpha \lambda$ íous) niech będą, godnymi, rozważnymi, zdrowi co do wiary, miłości i wytrwałości. Starsze [kobiety] podobnie, w zachowaniu godne czci, unikające oszczerstw czy uzależnienia od nad-

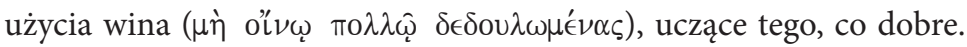
(Tt 2, 2-3)

O ile pierwsze wezwanie do bycia trzeźwym $(\mathrm{Tt}$ 2, 2), adresowane do starszych mężczyzn, może być rozumiane w sensie przenośnym, bo też na to wskazują najbliższe dwie postawy ( $\sigma \epsilon \nu$ ó $\varsigma, \sigma \omega ́ \phi \rho \omega \nu)$, o tyle w odniesieniu do starszych kobiet nie ma wątpliwości, iż idzie o nadużycie, a nawet uzależnienie od dużej ilości wina, jak można

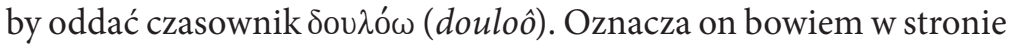
biernej i medialnej nie tylko być ujarzmionym jak niewolnik czy być związanym niewolą, ale także oddawać się w niewolę czy na służbę komuśs ${ }^{4}$. Zamiast więc uzależnienia od wina napominane mają oddać się na służbę Chrystusowi i zaangażować na rzecz szerzenia dobra ${ }^{45}$. Owe starsze kobiety zostały bowiem wezwane do nienagannego postępowania w każdej dziedzinie, jak na to wskazuje

43 Por. Katolicki komentarz biblijny, red. R. E. Brown, J. A. Fitzmyer, R. E. Murphy, pol. red. nauk. W. Chrostowski, Warszawa 2001, s. 1454 (Prymasowska Seria Biblijna).

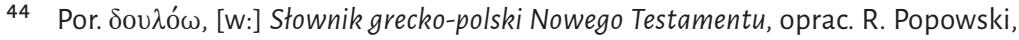
Warszawa 1999, s. 84.

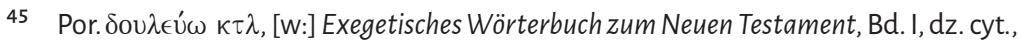
s. 851 . 
użyty termin $\kappa \alpha \tau \alpha \dot{\sigma} \tau \eta \mu \alpha\left(\right.$ katastêma ${ }^{46}$. Całym swoim zachowaniem winny one dawać dobry przykład, a przez to i pouczenie, młodszym. $\mathrm{Z}$ tego też zapewne powodu zarówno one, kobiety starsze, jak i biskupi oraz diakoni są napominani, by nie przebierali miary w piciu (1 $\mathrm{Tm} 3,3.8)$. Nie tylko więc należne kobietom poszanowanie wymaga, by nie nadużywały wina, a tym bardziej nie pozwalały sobie na uzależnienie od niego. Starsze kobiety, stawiane za wzór i pełniące funkcje nauczycielskie wobec młodszych kobiet, winny być i wzorem dla całej wspólnoty. Innymi słowy, choć napomnienie wprost do nich się odnosi, to jednak adresatem są wszystkie stany ${ }^{47}$.

Trzy moralne cnoty wymagane od starszych mężczyzn w omawianym wersecie Tt 2, 2 (trzeźwi, godni, rozważni) powtarzają się w Listach Pasterskich w odniesieniu do ludzi pełniących odpowiedzialne funkcje we wspólnocie. Tak $\nu \eta \phi \alpha ́ \lambda \iota$ เ (nêfalios), termin szczególnie nas interesujący, występuje jeszcze w odniesieniu do biskupów (1 $\left.\mathrm{Tm}_{3}, 2\right)$ oraz kobiet pełniących funkcję diakonisy (1 Tm 3, 11). Ważne przy tym jest i to, że trzeźwi, szanowani i rozsądni to ci, którzy postępują według zdrowej nauki ${ }^{48}$.

Mimo dostrzeganej jednostronności co do napomnień w analizowanym przez nas tekście (Tt 2, 2-3), bo wciąż z punktu widzenia mężczyzn, wspólny jest motyw odpowiednich zachowań. Jest nim nie tylko przykład dla innych członków wspólnoty (Tt 2, 7), ale także wzgląd na tych, którzy chcieliby oskarżać wyznawców Chrystusa o naganne życie (Tt 2, 8), oraz troska o to, by nie bluźniono słowu Bożemu $(2,5)$. Ostatecznie odpowiednie zachowanie, w tym i trzeźwość rozumiana w znaczeniu ścisłym i szerszym, stanowić mają wyraz zdrowej nauki, o jaką ma zadbać Tytus ${ }^{49}$.

Por. J. Stępień, Listy do Tesaloniczan i Pasterskie, dz. cyt., s. 391.

Por. L. Oberlinner, Der Titusbrief; F. Mussner, Der Jakobusbrief, Budapest 2002, s. 109. (Herders Theologischer Kommentar zum Neuen Testament [dalej: HThKNT]). Por. L. Oberlinner, Der Titusbrief; F. Mussner, Der Jakobusbrief, dz. cyt., s. 107. Por. O. Knoch, 1. und 2. Timotheusbrief. Titusbrief, Würzburg 1990, s. 75-76 (NEB 14). 
Bez określenia miary picia zostaje wyraźnie potępiona postawa nadużywania alkoholu, tak w sposób indywidualny, jak i zorganizowany. Motywacja jest nie tylko historiozbawcza - ma również wzgląd na godność człowieka i chrześcijanina oraz, co nie jest bez znaczenia, dobro innych członków wspólnoty.

\section{Trzeźwośćjest elementem etosu chrześcijanina $(1 \mathrm{P} 1,13 ; 4,7 ; 5,8)$}

Pierwszy List Świętego Piotra zawiera trzy wezwania do trzeźwości (1 P 1, 13; 4, 7; 5, 8), w różnych kontekstach. Pierwsze z nich (1 P 1, 13) pomieszczono na samym początku pierwszego pouczenia o charakterze parenetycznym (1 $\mathrm{P} 1,13-2,10)$, bezpośrednio zaś po przypomnieniu o nowym statusie adresatów listu. Status ten wynika z głoszonej, a poświadczonej w pismach, Dobrej Nowiny o zbawieniu (1 P 1, 10-12). Wezwanie do trzeźwości znajduje się w partii, którą można zatytułować „Wiara, nadzieja i świętość” (1 P 1, 13-21), jako że powtarzające się wezwanie do świętego życia wciąż odwołuje się do przypomnianej wcześniej wiary i nadziei (1 P 1, 3-9), całość zaś kończy się ponownym przywołaniem tych cnót (1 $\mathrm{P} 1,21)$. Najbliższy kontekst pierwszego wezwania do trzeźwości stanowi następujący fragment:

Dlatego przepasawszy biodra waszego umysłu, [bądźcie] trzeźwi, miejcie doskonałą nadzieję na łaskę, która wam przypadnie przy objawieniu Jezusa Chrystusa. [Bądźcie] jak posłuszne dzieci. Nie stosujcie się do waszych dawniejszych żądz, gdy byliście nieświadomi, ale w całym postępowaniu stańcie się wy również świętymi na wzór Świętego, który was powołał, gdyż jest napisane: Świętymi bądźcie, bo Ja jestem święty. (1 $\mathrm{P} 1,13-16$; BT)

Wezwanie motywowane jest świętością samego Boga, który wręcz wzywa swój lud - poprzez zawsze aktualne słowo Pisma - do bycia 
świętym (1 P 1, 16). Chodzi tu nie o świętość w sensie kultycznym, ale moralnym, na co wskazuje wezwanie do zerwania z posłuszeń-

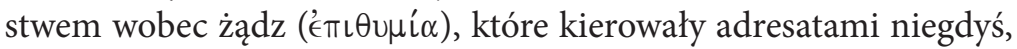
zanim jeszcze poznali oni nadzieję zbawienia (1 P 1, 14c). Zamiast dostosowywania się ( $\sigma \cup \sigma \chi \eta \mu \alpha \tau i \zeta o \mu \alpha \iota)$ do swoich żądz (1 P 1, 14b)

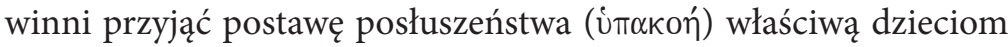
wobec ojca (1 P 1, 14a).

Takie posłuszeństwo wiąże się z gotowością do chłonnego przyjmowania tego, co ojciec mówi. Wyraża to pierwsze wezwanie, sformuło-

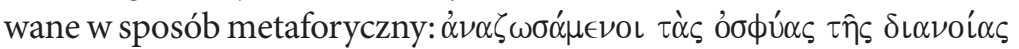
i $\mu \hat{\omega} \nu$ (1 $\mathrm{P}_{1}$ 1, 13a) - dosłownie można to przetłumaczyć „przepasawszy biodra waszego umysłu”, faktycznie zaś oznacza przygotowanie umysłu do działania. W takim kontekście pojawiający się imiesłów

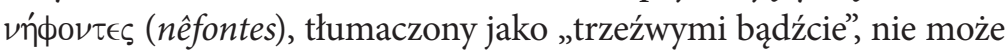
być rozumiany tylko jako powstrzymywanie się od wpływu używania alkoholu. Idzie o trzeźwość rozumianą jako „zwrócenie uwagi na coś” lub „bycie uważnym wobec czegoś”, wręcz o postawę wyrażoną gdzie

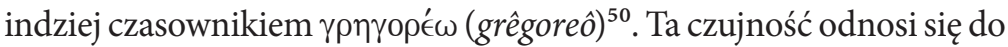
otrzymanego objawienia i do trwania w otrzymanej nadziei.

Zarówno wezwanie do gotowości, wyrażone sformułowaniem o przepasaniu bioder, znanym w świecie starożytnym w ogóle, a nie tylko w Biblii (por. Wj 12, 11; Łk 12, 35) ${ }^{51}$, jak i zachęta do trzeźwości, a przede wszystkim zapowiadane „objawienie się Jezusa Chrystusa” (1 $\mathrm{P} 1,13)$ wskazują na wspólny motyw - paruzję Pana, podobnie jak i we wcześniejszych wezwaniach (por. 1 Tes $5,5-8)^{52}$.

Na temat powiązań tej metafory ze słowami Jezusa w Ewangelii Łukasza: R. Gun dry, Verba Christi in I Peter. Their implications concerning the authorship of I Peter and the authenticity of the gospel tradition, NTS 13 (1966-1967), s. 339; R. Cundry, Further verba on verba Christi in First Peter, „Biblica” 55 (1974) No. 2, s. 224; E. Best, 1 Peter and the gospel tradition, NTS 16 (1969-1970), s. 104-105.

52 
Drugie wezwanie do trzeźwości w Pierwszym Liście Świętego Piotra $(1 \mathrm{P} 4,7)$ pojawia się także na początku kolejnej partii parenetycznej (1 P 4, 7-11), również - jak wcześniej omówione - powiązanej pod względem motywacji z paruzją i sądem. Wezwanie do trzeźwości wręcz wynika wprost z faktu bliskiego przyjścia Pana i końca tego czasu: „Wszystkich zaś [rzeczy] kres się przybliżył. Bądźcie więc rozsądni i trzeźwi, dla modlitwy" $(1 \mathrm{P} 4,7)$.

Występujący w tym wezwaniu czasownik $\sigma \omega \phi \rho o v \in ́ \omega$ (sôfroneô) oraz cel pożądanych postaw, jakim ma być modlitwa, każą i w tym tekście rozumieć trzeźwość ( $\nu \eta ́ \phi \omega)$ w szerszym tego słowa znaczeniu, zwłaszcza że także dalsze wskazania, zakończone doksologią (1 P 4, 8-11), lepiej wpisują się w kontekst wezwania do czujności i rozsądnego postępowania niż fundamentalne wezwanie do porzucenia pijaństwa. To ostatnie jest wprawdzie wprost wspomniane w partii poprzedzającej analizowany przez nas werset, co więcej - jako postawa adresatów listu, ale z ostatecznie minionej przeszłości. Tak bowiem trzeba rozumieć przypomnienie autora listu:

Wystarczy bowiem, żeście w minionym czasie pełnili wolę pogan i po-

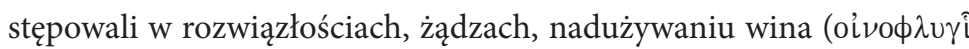

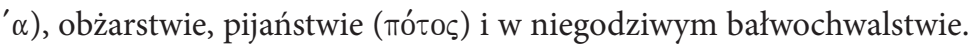
(1 $\mathrm{P}_{4}, 3$; BT)

Aż dwa techniczne określenia dla nadużywania alkoholu znalazły się w tym - raczej schematycznym - podsumowaniu stylu życia

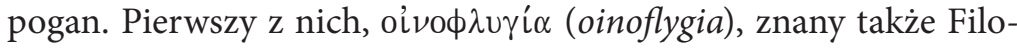
nowi (VitMos II, 185; SpecLeg IV, 91), oznacza pojedyncze przejawy uzależnienia od alkoholu ${ }^{53}$, drugi zaś, mótos (potos), odnosi się do

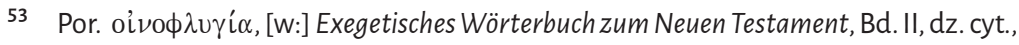
S. 1235. 
zbiorowego nadużywania tej substancji (pijatyka, libacja) ${ }^{54}$. Oba określenia występują w liczbie mnogiej, podobnie jak i inne w omawianym wykazie nagannych zachowań.

Wezwanie do rozsądku i trzeźwości w analizowanym wersecie 4, 7 dotyczy tego typu czujności, która dobrze służy modlitwie. Jest ono

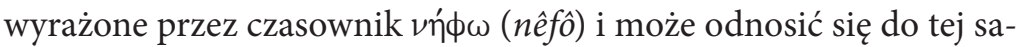

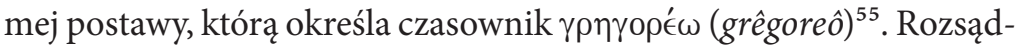
ne czuwanie, jak można też określić ów pożądany warunek modlitwy, zakłada postawę trzeźwości w sensie dosłownym, ale w niej się na pewno nie wyczerpuje. O potrzebie czuwania i modlitwy w obliczu pokusy poucza, ale także daje przykład, Chrystus w ewangelicznej scenie w Ogrodzie Oliwnym (por. Mt 26, 30. 36-46; Mk 14, 26. 32-42; Łk 22, 39-46; J 18, 1-2).

Trzeci tekst Pierwszego Listu Piotra wzywający do trzeźwości $(1 \mathrm{P} 5,8)$ stanowi element pouczenia odnośnie do przeciwstawienia się złu, za którym stoi Nieprzyjaciel. Jest to jedno z ostatnich pouczeń listu. Najbliższy jego kontekst stanowi następujący passus:

Bądźcie trzeźwi, czuwajcie! Nieprzyjaciel wasz, diabeł, jak lew ryczący krąży, usiłując [kogoś] pożreć. Jemu opierajcie się, mocni pod względem wiary, wiedząc, iż tych samych cierpień doświadczają wasi współbracia w świecie. (1 P 5, 8-9)

Zarówno występowanie obok wezwania do czuwania ( $\gamma \rho \eta \gamma o \rho \in ́ \omega)$, jak i powód pożądanej postawy, jakim jest opór wobec zakusów Złego, wskazują, że i w tym przypadku „być trzeźwym” ( $\nu \eta ́ \phi \omega)$ należy rozumieć w sensie przenośnym. Porównanie taktyki działania diabła

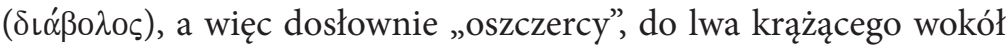
upatrzonej zdobyczy każe postrzegać owe „trzeźwość” i „czuwanie”

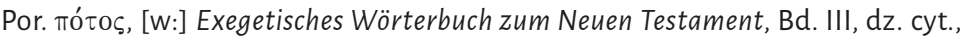
S. 342.

Por. J. R. Michaels, Word biblical commentary, Vol. 49, 1 Peter, dz. cyt., ad locum. 
jako postawy mądrej czujności wobec rozpoznawanej metody dzia-

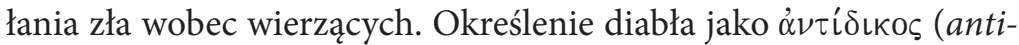
dikos), a więc „nieprzyjaciel”, „,adwersarz”, sugeruje, iż trzeźwy chrześcijanin nie pójdzie na kompromis, układ lub ugodę z nim, wiedząc, iż idzie o zdeklarowanego przeciwnika Boga i człowieka. Porównanie diabła do lwa ryczącego, którego celem jest pożarcie ofiary, wskazuje na to, że czujność i roztropność każą bardzo poważnie traktować każde posunięcie nieprzyjaciela. Żądza krwi i głód lwa w trakcie polowania, przywołane przez autora listu, w sposób dosadny ukazują zagrożenie ${ }^{56}$. Wreszcie taktyczne wskazania co do sposobu reagowania na ataki diabła („opierać się mocą wiary”) określają stronę zawsze atakującą (diabeł) oraz pozycję wierzącego (zawsze skazany na postawę „oporu”).

Wreszcie, na końcu, nie można nie zauważyć aspektu wspólnotowego owej trzeźwości. Idąc za porównaniem do lwa krążącego wokół stada, należy - w ramach „trzeźwej oceny sytuacji” - trzymać się wspólnoty. Lew bowiem atakuje jednostki, które udało mu się odłączyć od stada. Wspólnotowy aspekt ujawnia się w tym pouczeniu także na końcu, gdy autor listu stwierdza, iż podobne zagrożenia i cierpienia są udziałem wierzących na całym świecie.

\section{Od sług Kościoła wymaga się trzeźwości}

(1 Tm 3, 2-5. 8-13; Tt 1, 5-9)

W Listach Pasterskich, które są adresowane nie do całych wspólnot, a do pojedynczych osób, znalazły się wskazania dla biskupów, prezbiterów, diakonów i diakonis ${ }^{57}$. W „kwestionariuszach” dla ludzi

56 Por. K. H. Schelkle, Die Petrusbriefe. Der Judasbrief, dz. cyt., s. 132.

57 Nie podejmujemy w niniejszym opracowaniu ani problematyki autorstwa Listów Pasterskich i czasu ich powstania, ani też zagadnień dotyczących terminologii odnoszącej się do „hierarchicznej struktury Kościoła”. W języku polskim te ostatnie zagadnienia, stosunkowo obszernie i aktualnie wobec stanu badań sprzed 30 lat, 
podejmujących różne funkcje w Kościele pojawiają się także terminy odnoszące się do trzeźwości. Temat ten podjęty jest również w odniesieniu do samego Tymoteusza, jednak to ostatnie zagadnienie omówimy dopiero w następnym punkcie naszego opracowania.

Pierwszy List do Tymoteusza zawiera „kwestionariusze” dla kandydata na biskupa, diakona i diakonisę. Umieszczone one zostały w jednym bloku (1 Tm 3,1-13), po wcześniejszych pouczeniach adresowanych do mężczyzn i kobiet $(1 \mathrm{Tm} 2,8-15)^{58}$. Jako pierwsze w całym bloku znajdują się wymagania stawiane mężczyźnie okre-

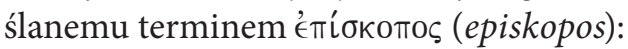

Biskup więc powinien być nienaganny, mąż jednej żony, trzeźwy ( $\nu \eta \phi \alpha ́ \lambda\llcorner\circ \varsigma)$, rozsądny, przyzwoity, gościnny, sposobny do nauczania,

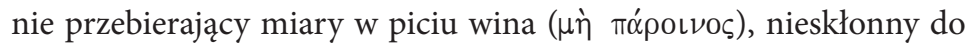
bicia, ale opanowany, niekłótliwy, niechciwy na grosz, dobrze rządzący własnym domem, trzymający dzieci w uległości, z całą godnością. Jeśli ktoś bowiem nie umie stanąć na czele własnego domu, jakżeż będzie się troszczył o Kościół Boży? (1 Tm 3, 2-5; BT)

Pouczenie o trzeźwości wymaganej od biskupa zawiera dwa różne terminy i ma za kontekst dwa typy wskazań. Wpierw został użyty termin $\nu \eta \phi \alpha ́ \lambda\llcorner o \varsigma$ (nêfalios), który - ze względu na najbliższy kontekst należy rozumieć $\mathrm{w}$ znaczeniu przenośnym. Ma być bowiem biskup człowiekiem o trzeźwym myśleniu ( $\nu \eta \phi \alpha ́ \lambda\llcorner o \varsigma)$ i pełnym rozsądku ( $\sigma \omega ́ \phi \rho o \nu)$, do tego dochodzą inne przymioty, które można określić

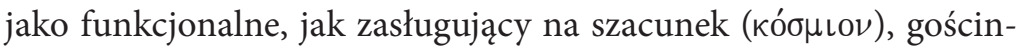

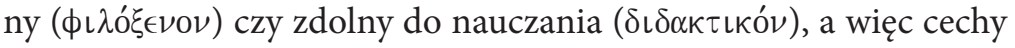

omawia J. Stępień w ekskursach, pomieszczonych w komentarzu. Por. J. Stępień, Listy do Tesaloniczan i Pasterskie, dz. cyt., s. 453-469. postępowaniu w „Domu Bożym” (1 Tm 3, 15); por. O. Knoch, 1. und 2. Timotheusbrief. Titusbrief, dz. cyt., s. 28. 
konieczne dla przewodzącego wspólnocie wierzących, a równocześnie jej reprezentanta na zewnątrz ${ }^{59}$. Na rozumienie trzeźwości wyrażonej przymiotnikiem $\nu \eta \phi \alpha ́ \lambda \iota$ c rzutuje też i fakt, że już w języku greckim pozabiblijnym odnoszony on bywa do sfery kultu, ofiar i kapłanów, a oznacza nie tylko „wolny od wina”, ale także stosowną jakośćco .

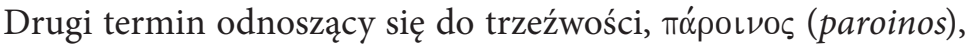
dotyczy już jednoznacznie nadużywania miary w piciu wina, zaś zakres znaczeniowy czasownika, z którego ten przymiotnik pochodzi, jest jednoznaczny. Czasownik $\pi \alpha \rho o \iota \nu ' \epsilon$ (paroineô) ${ }^{61}$ oznacza bowiem: „napastować po pijanemu, znęcać się, zachowywać się nieprzyzwoicie przy winie, wyprawiać coś po pijanemu, znieważać, źle traktować, postępować jak pijany"62. Dalsze określenia, następujące

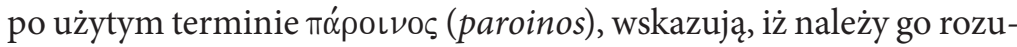
mieć w sposób dosłowny i dosadny, zaś najbardziej pojemnym zwrotem oddającym jego znaczenie w tym kontekście byłoby „niemoralny z powodu pijaństwa” ${ }^{63}$. Kolejne bowiem określenia: „nieskłonny do bicia, ale opanowany, niekłótliwy, niechciwy na grosz, dobrze rządzący własnym domem, trzymający dzieci w uległości, z całą godnością" (1 Tm 3, 3-4) stanowią cechy pożądane u każdego, kto jako pan domu, mąż i ojciec stoi na czele rodziny. Rozumowanie autora tego wykazu postaw dyskwalifikujących człowieka do funkcji biskupa jest proste: kto nie sprawdził się w prowadzeniu społeczności określanej jako familia, nie może stanąć na czele wspólnoty Kościoła. Jedną z cech przekreślających szansę na przyjęcie odpowiedzialności za wspólnotę

59 Por. L. Oberlinner, Der erste Timotheusbrief, Budapest 2002, s. 116-117 (HThKNT).

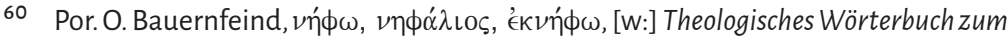
Neuen Testament, Bd. IV, dz. cyt., s. 938-940.

61 Czasownik ten, co ciekawe, nie występuje nigdzie w Nowym Testamencie, zaś w Septuagincie tylko raz $(I z 41,12)$.

62 Por. $\pi \alpha \rho \circ \nu \nu^{\prime} \omega$, [w:] Słownikgrecko-polski, t. II, dz. cyt., s. 167.

63 Por. п̊́ S. 100. 
wierzących jest zachowywanie się po pijacku, to zaś ujawnia się zazwyczaj przy jakimś zgromadzeniu ludzi, być może nawet w czasie wieczerzy Pańskiej (por. 1 Kor 11, 21) ${ }^{64}$.

Po wskazaniach odnoszących się do biskupów Pierwszy List do Tymoteusza daje pouczenie dla diakonów (1 Tm 3, 8-10), kobiet jak się przyjmuje, dość powszechnie pełniących podobne funkcje $(1 \operatorname{Tm} 3,11)$ - i po raz drugi dla diakonów $(1 \operatorname{Tm} 3,12-13)^{65}$. Przywołajmy ten fragment:

Diakonami tak samo winni być ludzie godni, w mowie nieobłud-

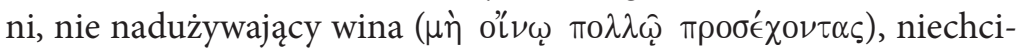
wi brudnego zysku, lecz utrzymujący tajemnicę wiary w czystym sumieniu. I oni niech będą najpierw poddawani próbie, i dopiero wtedy niech spełniają posługę, jeśli są bez zarzutu. Kobiety również czyste, nieskłonne do oczerniania, trzeźwe ( $\nu \eta \phi \alpha \lambda$ íous), wierne we wszystkim. Diakoni niech będą mężami jednej żony, rządzący dobrze dziećmi i własnymi domami. Ci bowiem, skoro dobrze spełnili czynności diakońskie, zdobywają sobie zaszczytny stopień i ufną śmiałość w wierze, która jest w Chrystusie Jezusie. (1 Tm 3, 8-13; BT)

Podobnie jak w odniesieniu do biskupów, tak i wobec kandydatów na diakonów wysuwa się oczekiwania o charakterze ludzkim, bo specyficznie religijne kryterium stanowi jedynie „utrzymujący tajemnicę wiary w czystym sumieniu" (1 $\operatorname{Tm} 3,9)$. Niektóre z kryteriów wręcz powtarzają się, jak i ogólna zasada: umiejący zarządzać domem nadają się do pełnienia odpowiednich funkcji we wspólnocie wierzących. Powiązanie wymienionych postaw w odniesieniu do życia rodzinnego i kościelnego trafnie opisuje współczesny komentator:

należy unikać wszystkiego, co mogłoby obciążać relację do wspólnoty: bowiem fałsz, niewiarygodność w słowie niszczą wzajemne zaufanie; obciążenie pijaństwem jako znak braku odpowiedzialności za siebie

Por. L. Oberlinner, Der erste Timotheusbrief, dz. cyt., s. 121-122.

Por. J. Stępień, Listy do Tesaloniczan i Pasterskie, dz. cyt., s. 345. 
i brak samoopanowania wykluczają zdolność do tego, by podejmować odpowiedzialność za innych; gdzie zaś myślenie i działanie człowieka jest opanowane przez pieniądz i żądzę posiadania, tam inni są oceniani według takich kryteriów i degradowani do roli obiektów własnej pożądliwości ${ }^{66}$.

Jak łatwo zauważyć, kryteria odnoszone do kobiet mających pełnić funkcję diakonis są wzięte $z$ wykazu dotyczącego albo biskupa, albo diakonów ${ }^{67}$. Prawdopodobnie zostały one dobrane ze względu na cechy kobiece przejawiające się w życiu wspólnoty i ich posłudze. Termin $\nu \eta \phi \alpha \lambda$ íos (nêfalios), odnoszony do kobiet diakonis, ze względu na kontekst należałoby rozumieć w sensie przenośnym (podobnie jak w wersecie 3, 2), a więc „trzeźwe w myśleniu i działaniu”. Takie rozumienie lepiej bowiem wpisuje się w ich opis i pożądane u nich zachowania, wymienione przez autora listu ${ }^{68}$.

W Liście do Tytusa funkcje przywódcze w Kościele pełnić mają lu-

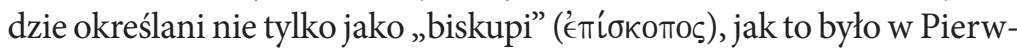
szym Liście do Tymoteusza, ale także jako „starsi” $(\pi \rho \in \sigma \beta u ́ \tau \epsilon \rho \circ \varsigma)^{69}$. Wymagania stawiane kandydatom do tych funkcji, które autor zdaje się traktować jako tożsame, na pewno zaś nie ustawia ich w relacji jakiejś zależności czy podporządkowania jednej od drugiej ${ }^{70}$, zostały sformułowane w jednym bloku:

Por. L. Oberlinner, Der erste Timotheusbrief, dz. cyt., s. 135.

Tekst nowotestamentowy wymieniający z imienia kobietę pełniącą funkcję diako-

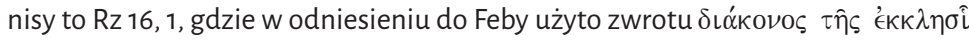

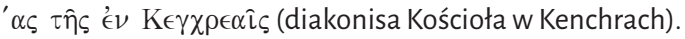

Por. L. Oberlinner, Dererste Timotheusbrief, dz. cyt., s. 139-140.

Nie zajmujemy się zagadnieniem, które umownie określa się jako hierarchiczny ustrój Kościoła, ani wzajemną relacją pomiędzy różnymi funkcjami. Problematykę przybliża, wraz z odniesieniem do innych podobnych tekstów (1 Tm 3, 2-12), L. Oberlinner, Der Titusbrief, dz. cyt., s. 16-18.

Por. Katolicki komentarz biblijny, dz. cyt., s. 1453. 
W tym celu zostawiłem cię na Krecie, byś zaległe sprawy należycie załatwił i ustanowił w każdym mieście prezbiterów. Jak ci zarządziłem, [może nim zostać] jeśli ktoś jest nienaganny, mąż jednej żony, mający dzieci wierzące, nie obwiniane o rozpustę lub niekarność. Biskup bowiem winien być, jako włodarz Boży, człowiekiem nienagannym, niezarozumiałym, nieskłonnym do gniewu, nieskorym do pijaństwa

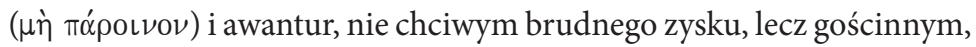
miłującym dobro, rozsądnym, sprawiedliwym, pobożnym, powściągliwym, przestrzegającym niezawodnej wykładni nauki, aby przekazując zdrową naukę, mógł udzielać upomnień i przekonywać opornych. $($ Tt $1,5-9)$

Biskup jawi się w tekście jako zarządzający Kościołem z mandatu

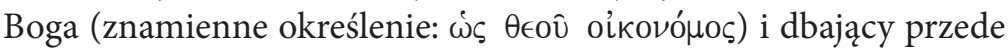
wszystkim o poprawność doktrynalną (Tt 1, 9). On też winien, właśnie jako „włodarz Boży”, jak to tłumaczy Biblia Tysiąclecia, posiadać cechy głęboko ludzkie, wśród których jest i wolność od pijackiego za-

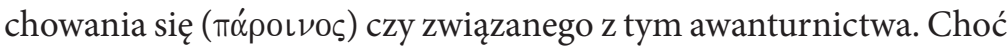
wykaz zdaje się dość schematyczny (pięć napiętnowanych występków oraz siedem cnót), to jednak zapewne zrodził się z obserwacji życiowych ${ }^{71}$. Istotne jest przy tym zaplecze teologiczne wypowiedzi, które stanowi rozumienie wspólnoty Kościoła jako „Domu Bożego”,

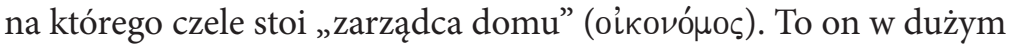
stopniu tworzy „atmosferę" tego domu. Z przywołanych występków, których nie powinno być, oraz pożądanych u biskupa cnót wynika, iż ma to być dom uporządkowany, z jasnym podziałem na obowiązki, dający domownikom poczucie bezpieczeństwa i stwarzający możliwość dialogu oraz poważnego traktowania wszystkich członków ${ }^{72}$. 
W takim domu nie ma miejsca na nadużywanie alkoholu ani na uczty sprzyjające zachowaniom pijackim.

Z Listów Pasterskich wynika jednoznacznie, że przełożeni Kościoła i podejmujący w nim odpowiedzialne funkcje winni być ludźmi trzeźwymi w podwójnym tego słowa znaczeniu. Wymóg taki bierze się z troski o dobro wspólnoty wierzących, idzie bowiem zarówno o funkcjonowanie Kościoła, jak i jego wierność Założycielowi, nie tylko co do ortodoksji, ale także i ortopraksji.

\section{Abstynencja i trzeźwość Tymoteusza}

(1 $\operatorname{Tm} 5,23 ; 2 \operatorname{Tm} 4,1-5)$

W Pierwszym Liście do Tymoteusza znajdziemy rzadką radę z dziedziny troski o zdrowie, w której kluczową rolę odgrywa odniesienie do używania wina. Owa rada została pomieszczona w kontekście bardzo osobistych wskazań autora listu, a dotyczących istotnych postaw i decyzji adresata. Wśród rad obejmujących odniesienie do ludzi grzeszących we wspólnocie Kościoła pojawia się wezwanie: „Już dłużej nie pij samej wody, lecz bierz nieco wina (olı względu na żołądek i częste twoje słabości!" $(1 \text { Tm 5, 23) })^{73}$.

Okazuje się, że adresat listu to przewodzący Kościołowi w Efezie (1 $\operatorname{Tm} 1,3)$, młody a równocześnie często zapadający na zdrowiu

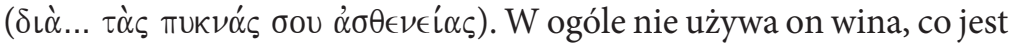
niezwykłe wobec powszechnego zwyczaju stosowania tego napoju, zwłaszcza do wieczornych posiłków. Ze względu na swój stan zdrowia Tymoteusz winien jednak zmienić swoje zasady, jak radzi, choć nie zmusza, zatroskany o niego autor $\mathrm{listu}^{74}$. O powodach całkowitej

73 Nie wiadomo, dlaczego w Biblii Tysiąclecia (także w wyd. 5) w tym miejscu występuje inna numeracja niż w wydaniach krytycznych greckiego Nowego Testamentu. Werset 5, 23 powinien zaczynać się bowiem od słów „Samej wody [...]”.

74 Por. C. S. Keener, Komentarz historyczno-kulturowy do Nowego Testamentu, red. nauk. wyd. pol. K. Bardski, W. Chrostowski, tłum. Z. Kościuk, Warszawa 2000, s. 478. 
abstynencji Tymoteusza tekst nic nie mówi. Poprzedzające zdanie określenie $\dot{\alpha} \gamma \nu o ́ \varsigma$ (hagnos), a więc „czysty”, co może oznaczać w tym kontekście „pod względem religijnym bez zarzutu” $(5,22)^{75}$, pozwala przypuszczać, iż dotąd Tymoteusz powstrzymywał się od używania wina, by moralnie wyraźnie oddzielić się od tych, którzy dopuszczali się różnych wykroczeń, być może i w dziedzinie trzeźwości ${ }^{76}$.

Przyjęcie założenia, iż List do Tymoteusza stanowi pismo pseudoepigraficzne, napisane już po śmierci Pawła, pozwala przypuszczać, iż w środowisku, w jakim powstało to pismo, istniały grupy, być może o charakterze gnostyckim, które demonstracyjnie powstrzymywały się od używania wina, by w ten sposób wyrazić swoją doskonałość i oddzielenie się od „złego świata”77. Wówczas takie pouczenie adresowane do Tymoteusza miałoby faktycznie służyć napomnieniu grupy, której powstrzymywanie się od picia wina mogło mieć niewłaściwą motywację lub wiązać się z podejrzaną teologią ${ }^{78}$.

W Drugim Liście do Tymoteusza temat trzeźwości pojawia się w jego końcowej partii $(2 \operatorname{Tm} 4,5)$. Kontekst stanowi tu trudna sytuacja Kościoła ze względu na mnożące się przykłady fałszywego nauczania. Dlatego autor listu zwraca się z żarliwym apelem:

Zaklinam cię wobec Boga i Chrystusa Jezusa, który będzie sądził żywych i umarłych, i na Jego pojawienie się, i na Jego królestwo: głoś naukę, nastawaj w porę, nie w porę, [w razie potrzeby] wykaż błąd, poucz, podnieś na duchu z całą cierpliwością, ilekroć nauczasz.

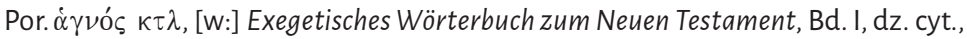
S. 52-54. Por. O. Knoch, 1. und 2. Timotheusbrief. Titusbrief, dz. cyt., s. 42. Tak też w: J. Stępień, Listy do Tesaloniczan i Pasterskie, dz. cyt., s. 367-368.

Por. J. Jeremias, A. Strobel, Die Briefe an Timotheus und Titus. Der Brief an die Hebräer, Cöttingen 1975, S. 43 (Neue Testament Deutsch, 9); J. Roloff, Der erste Brief an Timotheus, Zürich 1988, s. 315 (EKK 15). 
Przyjdzie bowiem chwila, kiedy zdrowej nauki nie będą znosili, ale według własnych pożądań - ponieważ ich uszy świerzbią - będą sobie mnożyli nauczycieli. Będą się odwracali od słuchania prawdy, a obrócą się ku zmyślonym opowiadaniom. Ty zaś czuwaj we wszystkim ( $\left.\nu \eta \hat{\phi} \in \epsilon^{\epsilon} \nu \pi \hat{\alpha} \sigma \iota \nu\right)$, znoś trudy, wykonaj dzieło ewangelisty, spełnij swe posługiwanie! (2 $\mathrm{Tm} 4,1-5 ; \mathrm{BT})$

Wezwanie do czuwania, i to we wszystkim, wyrażone czasownikiem odnoszącym się do trzeźwości ( $\nu \eta ́ \phi \omega)$, musi być odczytane w najbliższym kontekście, ten zaś stanowi żarliwa zachęta do wypełnienia nałożonego na adresata obowiązku (2 Tm 4, 5), zwłaszcza że idzie o walkę w czasach ostatnich ${ }^{79}$. Jego posługa ( $\delta\llcorner\alpha \kappa o \nu i ́ \alpha)$, tu przede wszystkim pasterska i nauczycielska, jest nie do pomyślenia bez takich elementów składowych jak czujność ( $\nu \eta ́ \phi \omega)$ wobec tego, co się w Kościele dzieje, znoszenie dotkliwych trudów z tym zwią-

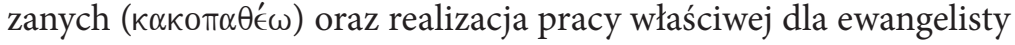

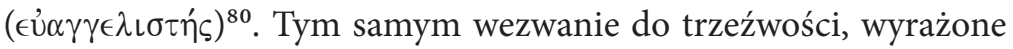

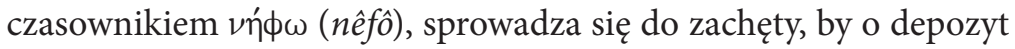
wiary i zbawienie powierzonych członków wspólnoty dbać, będąc w postawie czujnej roztropności ${ }^{81}$.

Przynagleniem dla pilnego i gorliwego wypełnienia powierzonej Tymoteuszowi misji powinno być i to, o czym Paweł pisze w następującym fragmencie, który tradycyjnie określa się jako „Testament Apostoła” ( 2 Tm 4, 6-18). Innym motywem dla tak rozumianej trzeźwości jest fakt, iż jest ona darem Boga, bo na początku tego listu pojawia się określenie specyficznego daru: „ducha trzeźwego myślenia” ( $\pi \nu \in \hat{v}$ $\mu \alpha \sigma \omega \phi \rho о \nu\llcorner\sigma \mu о \hat{)})$. Jest on przeciwny duchowi bojaźni, a towarzyszy takim darom jak „duch mocy i miłości” (2 Tm 1, 7).

Por. A. Weiser, Der zweite Brief an Timotheus, Düsseldorf-Zürich 2003, s. 304 (EKK XVI/1).

80 Por. J. Stępień, Listy do Tesaloniczan i Pasterskie, dz. cyt., s. 444.

81 Por. L. Oberlinner, Der zweite Timotheusbrief, Freiburg 1995, s. 157-158 (HThKNT). 
Tymoteusz jawi się jako pasterz Kościoła wrażliwy na zagrożenia doktrynalne i moralne. Nie ma potrzeby zachęcać go do trzeźwości, bo zachowuje abstynencję od napojów alkoholowych. Do wypełnienia obowiązków pasterskich potrzebuje jednak trzeźwości w znaczeniu przenośnym.

\section{Podsumowanie}

Temat trzeźwości w formie napomnień pojawia się w listach Pawłowych, zarówno autentycznych (1 Tes, Rz), jak i deuteropawłowych (1-2 Tm; Tt) oraz w Pierwszym Liście Piotra. Trzeźwość jest rozumiana w sensie i dosłownym, i przenośnym (szerszym). W pierwszym przypadku idzie o wolność od uzależnienia od alkoholu, powstrzymywanie się od jego nadużywania oraz zachowań podejmowanych pod wpływem lub w związku z pijaństwem. Trzeźwość w znaczeniu przenośnym to postawa życiowa, którą można też określić jako czujność i rzeczowość wynikające z motywacji religijnych oraz dla spraw religijno-moralnych.

Chrześcijanin ma być trzeźwy w potrójnym tego słowa znaczeniu. Bezdyskusyjne jest zachowanie umiaru w używaniu napojów alkoholowych oraz wolność od nałogu picia. Tym bardziej wykluczony jest udział w pijatyce lub takich ucztach, w których idzie o programowe upicie się i obżarstwo. Nie do pomyślenia jest również udział w uroczystościach religijnych ku czci bóstwa wina.

Chrześcijanina wzywa się także do wysiłku ducha, który też jest określany terminem „trzeźwość”. Wysiłek i zrodzona z niego postawa trzeźwości odnosi się do stylu życia, którego przeciwieństwo stanowi obojętność, brak świadomości i czujności. Trzeźwy chrześcijanin właściwie ocenia rzeczywistość oraz podejmuje odpowiedzialne decyzje. Trzeźwość wyraża się wreszcie w umiejętnej postawie wobec zła.

Trzeźwość w podwójnym tego słowa znaczeniu dotyczy wszystkich, którzy wierzą w Jezusa Chrystusa, w szczególny jednak sposób 
wymagana jest od tych podejmujących jakąś odpowiedzialność w Kościele, przewodzących wspólnocie, bo to oni mają realny wpływ na jakość jej życia. Od trzeźwości biskupa lub prezbitera, i to w podwójnym tego słowa znaczeniu, zależy nie tylko kondycja moralna Kościoła, ale także kształt nauczania. Trzeźwość wymagana jest także od kandydatów do funkcji diakońskich, a pożądana wśród osób zasługujących na szacunek we wspólnocie (starsi mężczyźni i kobiety).

Motywacja do chrześcijańskiej trzeźwości jest przede wszystkim religijna, dokładniej mówiąc - historiozbawcza. Zakłada ona znajomość podstawowego orędzia zbawienia i jego konsekwencji życiowych. To ze względu na pewne powtórne przyjście Pana nieodzowna jest trzeźwość, w miarę upływu czasu nawet coraz bardziej wydoskonalona. Innym motywem dla postawy trzeźwości jest dobro wspólnoty i jej poszczególnych członków. Dotyczy to zwłaszcza tych za nie odpowiedzialnych i mających wpływ na jej funkcjonowanie. Trzecim motywem dla trwania w postawie trzeźwości jest dobro osobiste, zagrożone przez zło i Złego. 